Int. J. Plant Sci. 180(4):323-336. 2019. (C) 2019 by The University of Chicago. All rights reserved. This work is licensed under a Creative Commons Attribution-NonCommercial 4.0 International License (CC BY-NC 4.0), which permits non-commercial reuse of the work with attribution. For commercial use, contact journalpermissions@press.uchicago.edu.

1058-5893/2019/18004-0004\$15.00 DOI: $10.1086 / 702643$

\title{
PINNULE AND STOMATAL SIZE AND STOMATAL DENSITY OF LIVING AND FOSSIL BOWENIA AND EOBOWENIA SPECIMENS GIVE INSIGHT INTO PHYSIOLOGY DURING CRETACEOUS AND EOCENE PALEOCLIMATES
}

\author{
Kathryn Edwina Hill, ${ }^{1, *}$ Robert Stephen Hill,* and Jennifer Robyn Watling† \\ *School of Biological Sciences and the Environment Institute, G05 Benham Building, North Terrace, University of Adelaide, Adelaide, \\ South Australia 5005, Australia; and +Ecology and Environment Research Centre, All Saints Building, \\ Manchester Metropolitan University, Manchester M15 6BH, United Kingdom
}

Editor: Michael T. Dunn

Premise of research. This study compares the pinnule morphology of three fossil Bowenia species, one Eobowenia (fossil) species, and several Bowenia fossil pinnule fragments with the two extant Bowenia species.

Methodology. Pinnule area, stomatal density, and size have been measured on fossil and extant specimens. Measures have been correlated with solar radiation and temperature to ascertain any correlations. Environment and climate variables have been chosen, as they have changed since the Eocene and Lower Cretaceous when the Australian and South American fossils were growing.

Pivotal results. Two of the fossil Bowenia species and Eobowenia have significantly smaller pinnules than the living species, and all the fossils have relatively small and sparse stomata compared with the living species. Extant Bowenia pinnule area is positively correlated with daily radiation and temperature.

Conclusions. Those fossil species with small pinnules likely lived in relatively dark environments where small pinnules aided the capture of sunflecks and/or facilitated light capture. The smaller and sparser stomata may have limited the potential sites for fungal invasion in the extremely humid growth conditions without hampering overall growth rates in the prevailing very high atmospheric $\mathrm{CO}_{2}$ levels.

Keywords: pinnule area, stomatal size, cycad, paleobotany, stomatal density, Australian cycad, South American cycad, Eocene, Cretaceous.

Online enhancements: appendix tables.

\section{Introduction}

Stomatal size and density are important leaf traits that determine the maximum bounds of leaf gas exchange. While stomata open and close in response to diurnal changes in environmental factors such as light, temperature, and water availability (Prior et al. 1997; Matthews et al. 2018), stomatal morphology varies over longer time scales in response to climate and other environmental variation (Franks and Beerling 2009; Hill et al. 2015). The same is true for leaf area, since the climate influences the leaf boundary layer thickness and photosynthetic area (Wright et al. 2017). This has been widely studied, and stomatal size and density have been shown to respond to humidity (El-Sharkawy et al. 1985; Gislerød and Nelson 1989), temperature (Frank et al. 1973; Limin et al. 2007), atmospheric $\mathrm{CO}_{2}$ concentration (Woodward 1987; Beerling and Kelly 1997; Bettarini et al. 1998;

\footnotetext{
${ }^{1}$ Author for correspondence; email: kathryn.hill@adelaide.edu.au.
}

Manuscript received July 2018; revised manuscript received December 2018; electronically published March 21, 2019.
Miller-Rushing et al. 2009), water availability (Gindel 1969; Limin et al. 2007), and light (Gay and Hurd 1975; Lake et al. 2001). The response of stomatal morphology and leaf area of fossil plants to climate can be quantified by comparing them with related extant species.

Bowenia Hook. ex Hook.f. is an endemic Australian cycad genus in the family Zamiaceae that contains two extant species in northeastern Australia. The recently described Eobowenia incrassata (S.Archang.) M.Coiro et C.Pott comb. nov. from the Aptian of Argentina (Coiro and Pott 2017) is included in the analysis, since it is regarded as the nearest fossil relative of Bowenia. Hill (1978) described two macrofossil species of Bowenia, based on pinnule remains, from Eocene sediments in southeastern Australia, and recently Hill et al. (2018) reviewed the macrofossil record of Bowenia and described a new Early Eocene species from Tasmania. Hill et al. (2018) noted that the three described fossil species had fewer and smaller stomata than those of the extant species, and two of the three fossil species had smaller pinnules than those of the extant species. The purpose of this article is to examine these differences in greater detail and in the context of the growth conditions that prevailed 
in southeastern Australia during the Eocene and in southern South America during the Lower Cretaceous.

Franks and Beerling (2009) showed that, in fossilized cycads, stomatal size varied thirteenfold and stomatal density changed eightfold among species growing between 200 and $40 \mathrm{Ma}$. These changes were probably a response to changes in environmental conditions. This makes the comparison of the stomatal traits of Australian Bowenia and South American Eobowenia with the extant Bowenia species very important, given the major environmental changes in Australia and globally during the last $\sim 125 \mathrm{Myr}$. The overall vegetation and habitat at each of the sites that contained the fossil species considered here is understood to varying degrees, but in no case is this understanding close to complete, so information gathered from these fossils has broad impact in assessing how these plants coped in such different environments.

The preservation of most of the fossils considered here allowed a detailed examination of the pinnule area and stomatal density and size. Thus, an assessment of the environments inhabited by these fossil species has been conducted. We investigated relationships between stomatal density, size, and pinnule area with reconstructed changes in light, temperature, rainfall, humidity, and atmospheric $\mathrm{CO}_{2}$ levels. We compared these traits among the fossil species and the two extant species of Bowenia and Eobowenia using fossils, herbarium specimens, and contemporary material collected in the field. The fossil Bowenia and E. incrassata specimens are compared with the extant Bowenia species.

\section{Material and Methods}

\section{Extant Specimens}

Extant Bowenia is an understory plant with a reduced stem and usually a single whorl of leaves. Five Bowenia spectabilis (Hook.f.) specimens were collected from Butchers Creek on

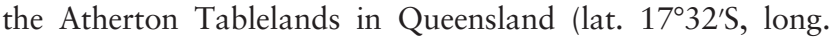
$145^{\circ} 69^{\prime} \mathrm{E}$ ) in April 2012. Thirty-five more B. spectabilis and 13 Bowenia serrulata (W.Bull) Chamb. specimens were supplied by the Queensland Herbarium, the National Herbarium of Victoria, and the Australian Tropical Herbarium, spanning $115 \mathrm{yr}$ from 1891 to 2006 for B. serrulata and $147 \mathrm{yr}$, from 1865 to 2012 for B. spectabilis. Specimen details are available in tables A1 (B. spectabilis) and A2 (tables A1, A2, B1, C1 are available online) (B. serrulata). Examples of specimen cuticle images are in figure 2.

\section{Preparation of Cuticles}

Cut from the margin were $1 \mathrm{~cm}^{2}$ pieces of pinnule. Pinnule pieces were placed into test tubes and covered in $80 \%$ ethanol $\mathrm{v} / \mathrm{v}$ overnight. The ethanol was then replaced with a $2: 1$ solution of $35 \% \mathrm{w} / \mathrm{v}$ hydrogen peroxide and $80 \%$ ethanol v/v and gently heated until the pinnule pieces turned translucent. The pinnule pieces were then rinsed with reverse-osmosis ( $\mathrm{RO}$ ) water and placed under a dissecting microscope so that debris could be brushed away from the cuticle, which was then rinsed with RO water. Cuticles were then stained with crystal violet and mounted on slides in phenol glycerine jelly. All cuticle slides prepared for this project are housed at the University of Adelaide.

\section{Cretaceous Climate: South America}

The Anfiteatro de Ticó Formation is located in Patagonia, Argentina (Coiro and Pott 2017). At the time of fossil deposition, the Aptian, the site was at an extremely high southern latitude of more than $60^{\circ} \mathrm{S}$ (Archangelsky and Archangelsky 2013).

The region had a rich diversity of cycads (Archangelsky 2001; Del Fueyo 2007), including xeromorphic species (Villar de Seoane 2005). However, the characters interpreted as xeromorphic by these authors may also be interpreted as adaptation to ash fall from surrounding volcanoes. Volcanism is stressful for plants, and many cycads had thick cuticles, papillae, and stomatal wax plugs to cope with these conditions (Haworth and McElwain 2008; Passalia et al. 2010). Because of the high volcanism, the sun was probably regularly blocked by ash fall and thus Eobowenia incrassata would have often persisted in low light conditions. This may have also created an environment of acid precipitation and burial following volcanic events ( $\mathrm{Li}-$ marino et al. 2012). During the Aptian, conditions in the area were warm with a dry season including intermittent humidity caused by volcanism (Limarino et al. 2012). Atmospheric $\mathrm{CO}_{2}$ conditions were high, with some estimates up to $2500 \mathrm{ppm}$, although many estimates of Aptian $\mathrm{CO}_{2}$ are $\sim 1100 \mathrm{ppm}$ (Wang et al. 2014).

\section{Eocene Climate: Australia}

The Australian macrofossil taxa were recovered from Campanian-Maastrichian and Early and Middle Eocene sediments. During the Eocene, Australia was beginning to separate from Antarctica and was $\sim 20^{\circ}$ farther south than at present. However, the prevailing climate at that latitude was very different than it is today. A combination of several features (ocean circulation patterns, atmospheric composition, and $\mathrm{CO}_{2}$ levels, and the general configuration of the continents) meant that the temperatures during the first half of the Eocene were much higher than they are today, and this is particularly notable at high southern latitudes. Carpenter et al. (2012) used three proxies to estimate that the Early Eocene site in Tasmania that contains one of the fossil Bowenia species (Bowenia johnsonii; Hill et al. 2018) had a near-tropical mean annual temperature estimate of $\sim 24^{\circ} \mathrm{C}$. Despite the extremely high southern latitude of Tasmania at the time (see fig. 2), McGowran and Hill (2015) noted that the so-called greenhouse-to-icehouse transition has included the Early Eocene climatic optimum, which was the warmest time for $85 \mathrm{Myr}$. This truncated sharply about $50 \mathrm{Ma}$, followed by the Middle Eocene climatic optimum and successive shifts in temperature through to the present day. The extent of these Eocene warm periods was such that there is no evidence of ice in Antarctica in the Late Paleocene and Early Eocene, and this remained the case until the early Late Eocene (Francis et al. 2008)

Australia has been moving northward relatively rapidly since its complete separation from Antarctica about 33.5 Ma (Cande and Stock 2013), meaning that all fossil locations were significantly farther south when the plants that produced these fossils 

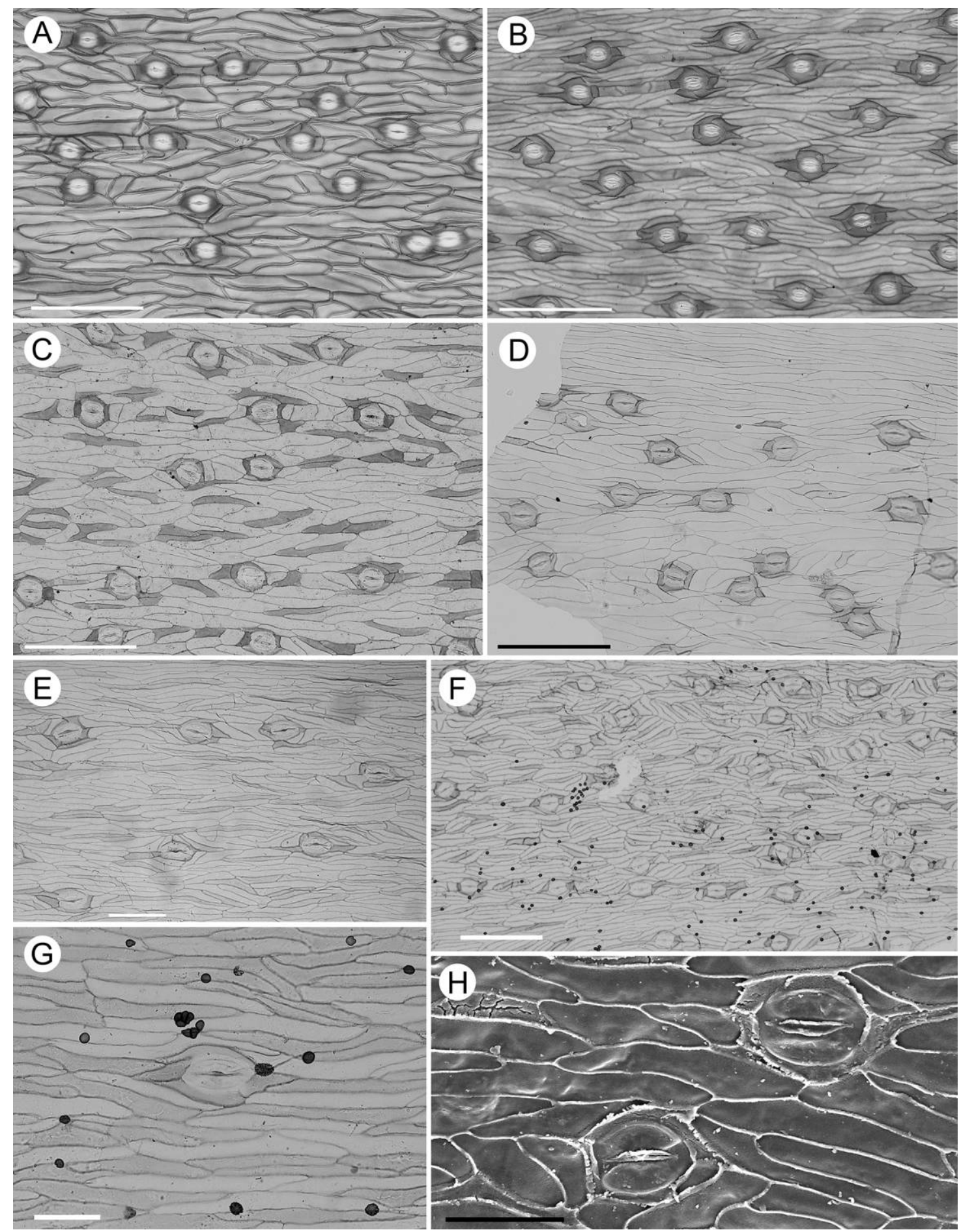

Fig. 1 Cuticle images of living and fossil Bowenia species ( $A-G$, light micrographs; $H$, scanning electron micrograph). Extant species Bowenia serrulata $(A)$ and Bowenia spectabilis $(B)$ showing the abaxial surface with several stomata present. C, Early Eocene Bowenia johnsonii from Lowana Road, showing the probable abaxial surface. D, Late Eocene Bowenia sp. from the Rundle locality, showing the probable abaxial surface. E, Late Middle Eocene Bowenia eocenica from the Anglesea locality, showing the probable abaxial surface. F, Probable abaxial surface of B. eocenica from Anglesea, showing a high density of fungal epiphyllous germlings (sensu Lange 1978). G, A single stoma of B. eocenica from Anglesea, showing several epiphyllous germlings attached to the cuticle surface. $H$, Inner cuticular surface of B. johnstonii from Lowana Road, showing the clearly defined stomatal apparatus and the relatively thin cuticular layer between epidermal cells. Scale bars $=200 \mu \mathrm{m}(A-D, F)$, $100 \mu \mathrm{m}(E)$, and $50 \mu \mathrm{m}(G, H)$. 


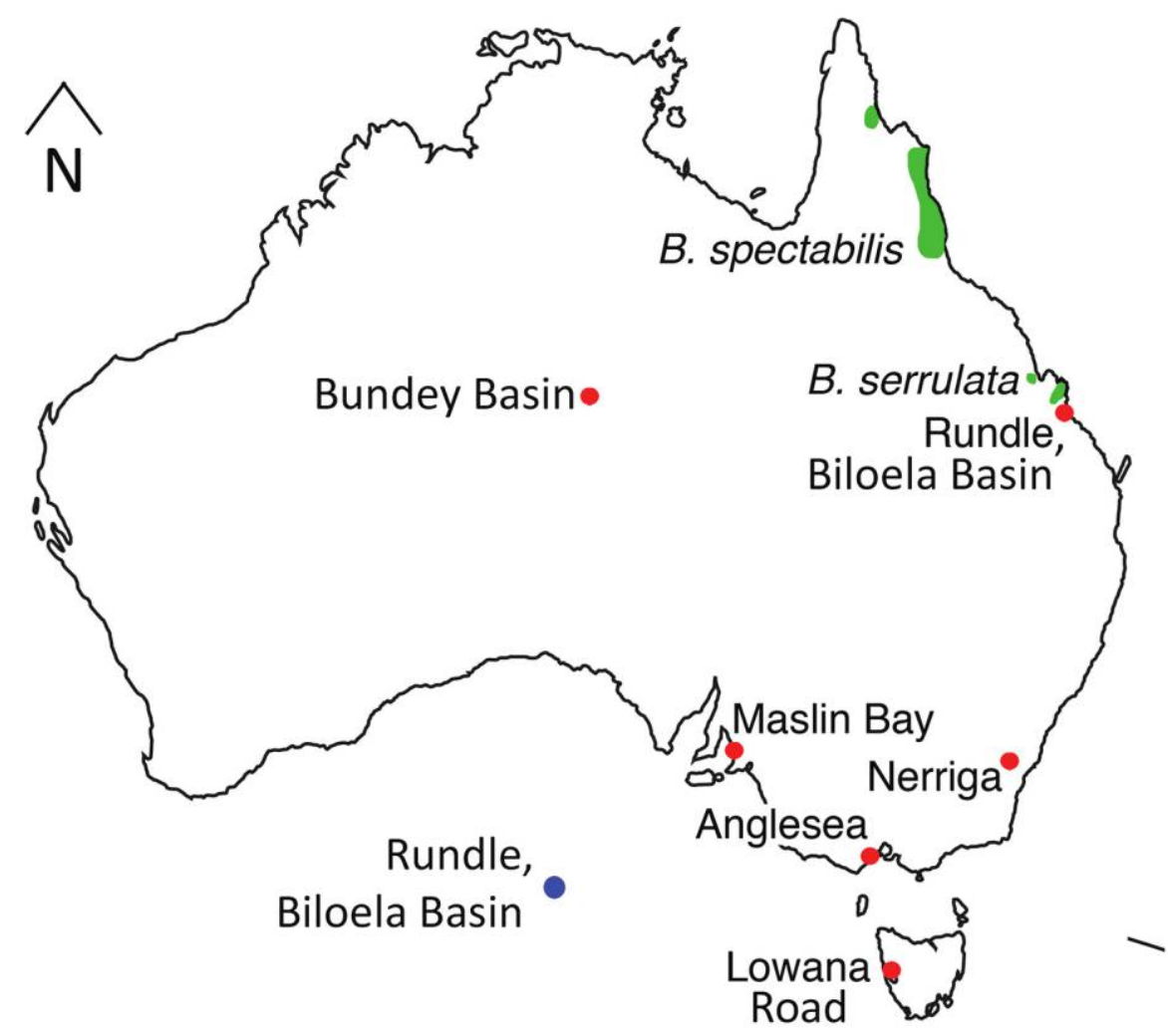

$40^{\circ} \mathrm{S} \quad$ Bundey Basin

Nerriga

$150^{\circ} \mathrm{S}$

Maslin Bay

Anglesea

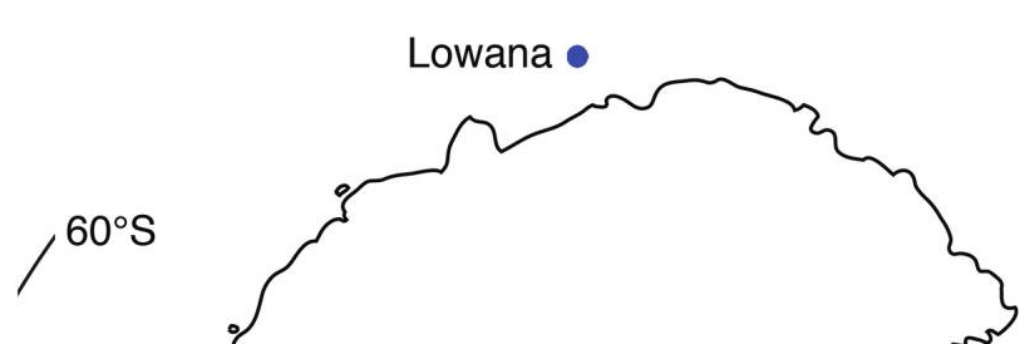

Fig. 2 Map of Australia showing the distribution of the living Bowenia species (green), fossil localities considered in detail in this study (red), and approximate palaeolatitude of the fossil localities (as stated by Wilford and Brown 1994) relative to southern Australia and Antarctica as they are placed today (blue).

were growing. The palaeolatitude of each fossil location can be estimated, and from that estimate the mean daily irradiance can be calculated, based on modern levels. However, for at least the Eocene localities, there is a high probability that heavy cloud cover was much more prevalent than it is now (Sloan and Rea
1996), so these irradiance estimates should be regarded as maximum possible values. It should also be noted that small understory plants like Bowenia (assuming the fossil species had a similar habit to the two extant species) would have received much less of this radiation than canopy plants. Mean daily irradiance 
of the Rundle fossil location (most northerly; fig. 2) site during the Late Eocene is estimated to be $446 \pm 20 \mathrm{~W} \mathrm{~m}^{-2}$ (Laskar et al. 2004), while the irradiance for the most southerly fossil site, Lowana Road, was estimated to be $425 \pm 19 \mathrm{~W} \mathrm{~m}^{-2}$ (for insolation calculation information, see table 1; Laskar et al. 2004). The current mean irradiance of the sites where extant Bowenia grows is $\sim 436.8 \mathrm{~W} \mathrm{~m}^{-2}$ for B. serrulata and 441.4 $\mathrm{W} \mathrm{m}^{-2}$ for B. spectabilis (Shellito et al. 2003; Laskar et al. 2004). It is also important to note that at the high latitudes where the plants that produced the fossils were growing, the sun has a daily track that remains relatively close to the horizon. Hence, it must have been particularly challenging for understory plants to receive adequate sunlight for growth, since shading from surrounding vegetation and topography is likely to have been high.

Other important plant growth factors were probably water availability and atmospheric $\mathrm{CO}_{2}$, both of which varied during the past and up to the present day. There is abundant evidence that Australia had very high humidity during the Early-Middle Eocene (Martin 2006) and perhaps levels not recorded anywhere on Earth today (Hill 2004). But by the end of the Late Eocene, the climate had started to dry, for a variety of reasons, including Australia's separation from Antarctica and the initiation of the circum-Antarctic Ocean Current (Hill 2004) and declining atmospheric $\mathrm{CO}_{2}$ levels (Anagnostou et al. 2016). Atmospheric $\mathrm{CO}_{2}$ levels during the Late Campanian-Maastrichtian were $\sim 800$ ppm (Wang et al. 2014). During the Early Eocene $\mathrm{CO}_{2}$ levels were possibly up to $1400 \mathrm{ppm}$, but by the beginning of the Late Eocene they had dropped to $\sim 770 \mathrm{ppm}$ (Anagnostou et al. 2016). Carbon dioxide levels continued to fall to less than $300 \mathrm{ppm}$ in the Holocene, until the commencement of the Industrial Revolution, and the level is now above $400 \mathrm{ppm}$ and rising (Tans and Keeling 2017).

\section{Extant Climate}

Environmental conditions for locations of the B. spectabilis and $B$. serrulata collections were obtained from the Atlas of Living Australia (http://spatial.ala.org.au/\#). The data collected from this website are available in table B1. All definitions of environmental variables pertaining to these collections were obtained from the Atlas of Living Australia (http://spatial.ala.org .au/\#) and are defined as follows: (1) minimum month evaporation ( $\mathrm{mm}$; minimum evaporation of any monthly evaporation), (2) minimum month vapor pressure deficit (KPa), (3) precipitation during the wettest month $(\mathrm{mm}$; maximum rainfall of any monthly rainfall), (4) radiation during the lowest period of the day ( $\mathrm{MJ} \mathrm{m} \mathrm{m}^{-2} \mathrm{~d}^{-1}$; Bio22), and (5) maximum temperature $\left({ }^{\circ} \mathrm{C}\right.$; maximum temperature of any monthly maximum temperature). Atmospheric $\mathrm{CO}_{2}$ when the contemporary Bowenia specimens were collected in 2012 was 397 ppm (Tans and Keeling 2017), which is an increase of $\sim 100$ ppm since the beginning of the previous century (Etheridge et al. 1998), when the earliest herbarium specimens were collected.

\section{Fossil Pinnules and Cuticles}

All fossil specimens had been prepared previously and were either retrieved from the University of Adelaide's David T. Blackburn Palaeobotany Collection, the South Australian State Herbarium, the Melbourne Museum, the University of Tasmania, or publication images. To maximize fossil data, any cuticle or pinnule remains that can be assigned to Bowenia have been included. When they have not been allocated to species, they will be referred to by their site names. Bundey Basin Bowenia has been described - although not formally - as indistinguishable from extant Bowenia (Carpenter et al. 2015). The Rundle/Biloela Basin sites have also been found to contain cuticles of Bowenia (Macphail et al. 2014); these are also not described (Foster and Harris 1981; Rowett 1988; Macphail et al. 2014). The final site containing Bowenia not formally described is Maslin Bay (McGowran et al. 1970). Eobowenia has been included because it is a sister group to Bowenia, and the two genera have a Gondwanan distribution (Coiro and Pott 2017). The general morphology of the fossils and their identification is found in Hill (1978), Coiro and Pott (2017), and Hill et al. (2018). For further details, see table C1.

\section{Measurements}

Cuticles were examined with an Olympus AX70 microscope, and cuticle photos were taken using the AnalySIS (ver. 6.0.6001 Service Pack 1 Build 6001, Acer, Australia) software. Stomatal density (stomata $\mathrm{mm}^{-2}$ ) was measured on both the fossil and extant pinnule cuticles by drawing a box measuring $400 \times$ $400 \mu \mathrm{m}$ on the cuticle photo and counting the number of stomata per box. Stomatal density was determined as the number of stomata per $\mathrm{mm}^{2}$. Stomatal size $\left(\mu \mathrm{m}^{2}\right)$ was calculated as the product of the length and width of between two and six guard cell pairs per piece of cuticle. Replication varied depending on availability of pinnules (B. johnsonii, $n=5$; Bowenia eocenica R.S. Hill, $n=3$; Rundle/Biloela Basin, $n=2$; Bowenia papillosa R.S. Hill,

\section{Table 1}

Location and Age of the Fossil Sites

\begin{tabular}{|c|c|c|c|}
\hline Site & Location (lat., long.) & Age (mya) & References \\
\hline Lowana Road & $42^{\circ} 11^{\prime} \mathrm{S}, 145^{\circ} 22^{\prime} \mathrm{E}$ & Early Eocene 56-47.8 & Carpenter et al. 2012 \\
\hline Nerriga & $35^{\circ} 07^{\prime} \mathrm{S}, 150^{\circ} 05^{\prime} \mathrm{E}$ & $\begin{array}{l}\text { Early-Middle Eocene } \\
\text { boundary } 47.8\end{array}$ & $\begin{array}{l}\text { Wellman and McDougall 1974; Truswell } \\
\text { and Owen } 1988\end{array}$ \\
\hline Maslin Bay & $35^{\circ} 13^{\prime} \mathrm{S}, 138^{\circ} 29^{\prime} \mathrm{E}$ & Early Middle Eocene 56-38 & McGowran et al. 1970 \\
\hline Anglesea & $38^{\circ} 25^{\prime} \mathrm{S}, 144^{\circ} 11^{\prime} \mathrm{E}$ & Late Middle Eocene 47.8-33.9 & Christophel et al. 1987 \\
\hline Rundle/Biloela Basin & $23^{\circ} 40^{\prime} \mathrm{S}, 151^{\circ} 10^{\prime} \mathrm{E}$ & Late Eocene $38-33.9$ & $\begin{array}{l}\text { Foster and Harris 1981; Rowett } 1988 \text {; } \\
\text { Macphail et al. } 2014\end{array}$ \\
\hline Bundey Basin & $\sim 22^{\circ} 39^{\prime} \mathrm{S}, 135^{\circ} 15^{\prime} \mathrm{E}$ & Late Campanian-Maastrichtian & Carpenter et al. 2015 \\
\hline Estancia Bajo Grande, Argentina & $46^{\circ} 57^{\prime} \mathrm{S}, 69^{\circ} 17^{\prime} \mathrm{W}$ & Lower Cretaceous (Aptian) & Coiro and Pott 2017 \\
\hline
\end{tabular}


$n=1$; and Maslin Bay, $n=1$; Bundey Basin, $n=1$; Eobowenia incrassata, $n=1$; B. serrulata, $n=13$; B. spectabilis, $n=40$ ). Stomatal index was difficult to measure consistently due to the distribution of the stomata in bands. This made measurements on fossil material difficult, as small pieces of cuticle often yielded less than one band; thus, stomatal index is not considered here.

Whole-pinnule ( $n=19$; table C1) images of herbarium, field-collected, and fossil specimens were captured using a CanoScan Toolbox version 4.9.3.2toolpak (X for Mac OSX) flatbed scanner. Pinnule area $\left(\mathrm{mm}^{2}\right)$ was determined with Image J 1.44p (Rasband 1997-2014). Whole-pinnule fossil images were only available for B. eocenica, B. papillosa, and B. johnsonii, and even then extrapolation was sometimes required to determine pinnule area (see images in Hill et al. 2018).

Shapiro-Wilk tests and multiple linear models with analysis of variance run on modern data used RStudio (RStudio Team 2015). Subsequently, the presence of interactions between variables that had significant effects on pinnule anatomy or size were tested. Due to the nature of the fossil material there was a very low rate of replication and, as such, a random mixed effects model was inappropriate. We present these data at face value, although we are aware that higher replication would improve the robustness of the work.

\section{Results}

Stomatal density and size did not correlate with each other for the entire $125 \mathrm{Myr}$ time frame $\left(R^{2}=0.02, P=0.09\right.$; fig. 3). Stomatal size of all fossil taxa is significantly smaller than their extant counterparts, except for Bowenia papillosa and the Maslin Bay specimen, which are not significantly different than either the fossil or extant species (fig. 4), although they overlapped at the small size range of the extant species. Stomatal density of four of the five measurable fossil species was not significantly different from either the other fossil or extant species (fig. 5). Bowenia johnsonii had significantly fewer stomata per unit area than the extant species. Stomatal data did not correlate with any environmental variables. Pinnule area of extant specimens correlated with low periods of irradiation $\left(R^{2}=\right.$ $0.12, P<0.0001$; fig. 6$)$ and maximum temperatures $\left(R^{2}=\right.$ $0.13, P<0.0001$; fig. 7). There were no significant correlations between stomatal size and density with any climate parameters tested (table B1). Pinnule area also did not significantly correlate with these variables.

Figure 8 is an illustration of pinnule area of all known species of Bowenia (note mean values for these measures in table 2). The area of the fossil Bowenia eocenica and Eobowenia pinnules is significantly smaller than that of the extant pinnules. The pinnule area of $B$. papillosa is not significantly smaller than one extant species, Bowenia serrulata, but it is also not significantly different from B. eocenica and Eobowenia incrassata. Bowenia johnsonii pinnule area is significantly larger than that of B. eocenica and E. incrassata and not significantly different in size from one extant species, B. serrulata. Extant Bowenia spectabilis has significantly larger pinnules than any others measured.

When fossil and extant pinnules are grouped together, their characters correlate to the large-scale $\mathrm{CO}_{2}$ change that has occurred between the Cretaceous and the present (fig. 9).

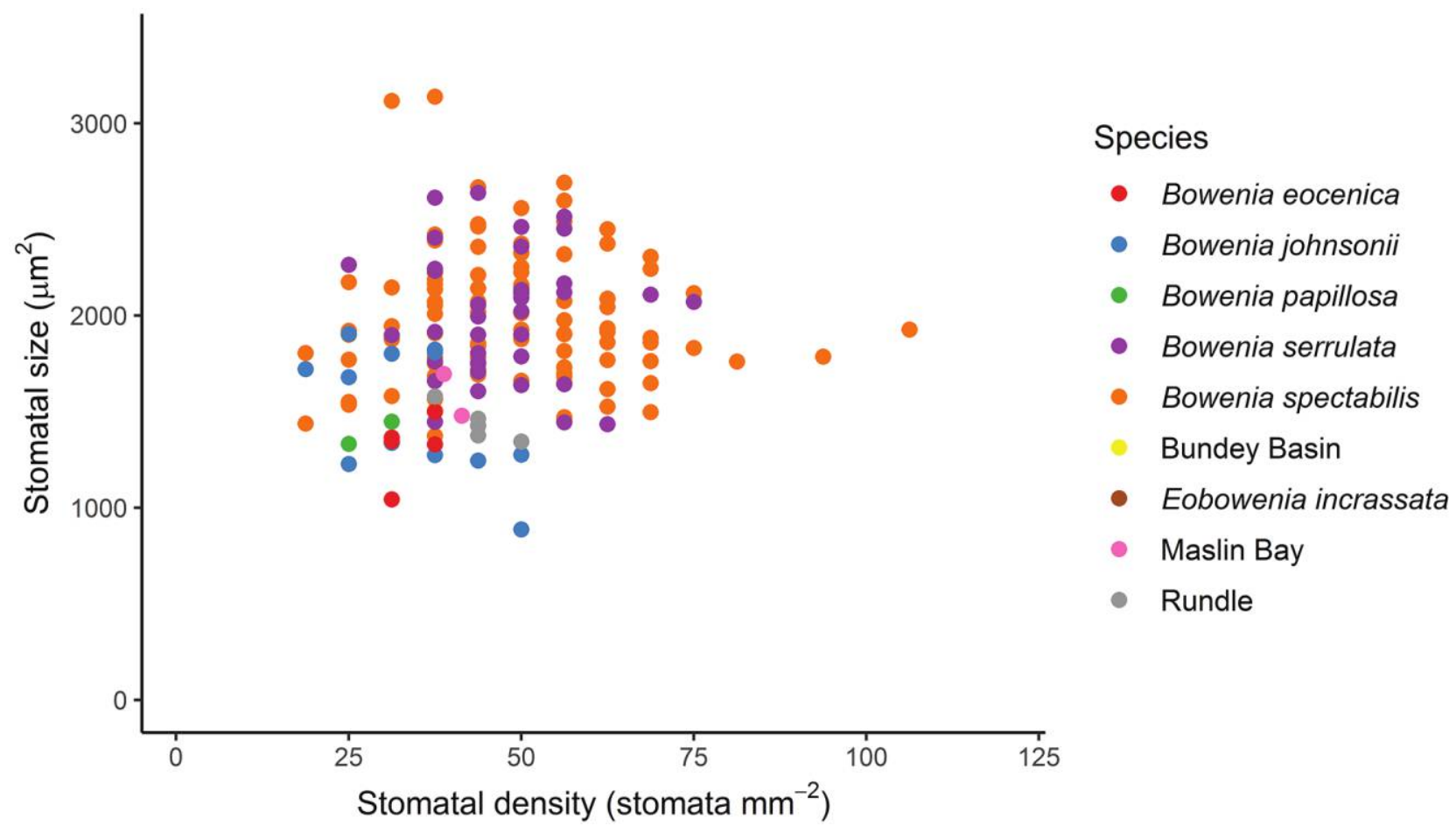

Fig. 3 Stomatal density and size for pinnules of the six Australian fossils, one South American fossil, and two extant species used in this study $\left(R^{2}=0.02, P=0.09\right)$. 


\section{Discussion}

The fossil Bowenia and Eobowenia specimens considered here tended to have fewer, smaller stomata and smaller pinnules than extant species. While for some taxa this was based on only one or a few specimens, it was relatively consistent and where more specimens were available (Bowenia eocenica and Bowenia johnsonii), although $B$. johnsonii had significantly larger pinnules. The range of stomatal density and size reported in this study (fig. 3) is similar to that found for cycads in other studies, but it is considerably higher than in most angiosperms (e.g., Franks et al. 2009; Drake et al. 2013). Haworth et al. (2011) reported a range of stomatal densities for six cycad species of 30-80 stomata $\mathrm{mm}^{-2}$, whereas the results of this study found stomatal density of Bowenia species to be $18-107$ stomata $\mathrm{mm}^{-2}$. This is a much larger range than that found by Haworth et al. (2011), and this large range is due to changes in one of the extant species, Bowenia spectabilis. All other Bowenia and Eobowenia incrassata had a range of between 3 and 50 stomata $\mathrm{mm}^{-2}$. Bowenia spectabilis occupies a much larger environmental range than any other species tested here (fig. 2) and thus has a larger range of pinnule morphology. Cycads growing during the Phanerozoic have been shown to have a stomatal size of up to $3000 \mu \mathrm{m}^{2}$ (Franks and Beerling 2009), and extant Bowenia species can match this at the high end of their range (fig. 3).

The major environmental differences between the extant and fossil environments are irradiance, atmospheric $\mathrm{CO}_{2}$, tempera- ture, relative humidity, and ash fall. The results suggest that pinnule size in extant species is positively correlated with radiation (fig. 6) and temperature (fig. 7); and these are potentially additive effects on pinnule size. Small pinnules are advantageous in shaded environments where light is both low and unpredictable, because they reduce the effects of self-shading (Falster and Westoby 2003) and thus increase the potential to capture sunflecks (Pearcy and Yang 1996). This may be the case for the fossil Bowenia (except B. johnsonii) and Eobowenia, as they tend to be smaller than the extant species (fig. 8).

The relatively small size of the pinnules at Anglesea, Nerriga, and the Anfiteatro de Ticó Formation (named B. eocenica, $B$. papillosa, and E. incrassata, respectively) requires careful consideration. Both Australian sites, and especially Anglesea, are characterized by a high angiosperm species diversity and relatively large leaves (Christophel 1980, 1984; Basinger and Christophel 1985; Christophel and Lys 1986; Christophel et al. 1987; Hill and Christophel 1988; Carpenter et al. 2016), both of which have been taken to indicate vegetation with relatively tropical affinities (Christophel et al. 1987), despite the very high latitudes at which they grew. The Anfiteatro de Ticó Formation had a contrasting environment during the Aptian, with low angiosperm and high gymnosperm diversity, and angiosperms present were nymphaeaphyllous (Passalia et al. 2014). Nymphaephyllous taxa are the most basal angiosperms with large, rounded leaves similar to those of floating plants (Krassilov 1977). Volcanism dominated the open landscape (Del Fueyo 2007) leading

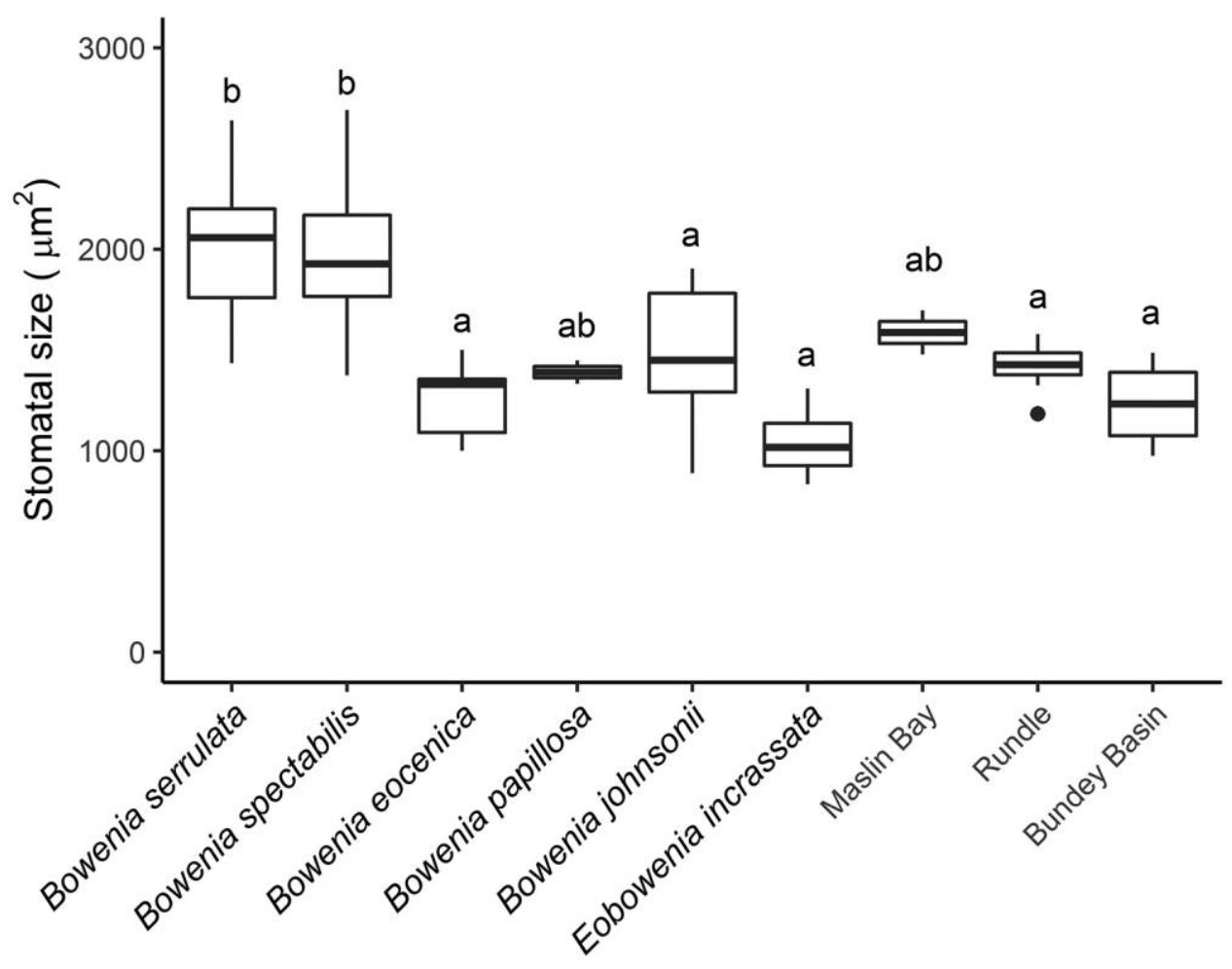

Fig. 4 Boxplots of stomatal size for all known Bowenia and Eobowenia species. The top and bottom hinges are the 25th and 75 th percentiles, respectively. The top and bottom whiskers end at the highest or lowest values, no larger than a multiple of 1.5 times the interquartile range. Data points extending beyond the whiskers are outliers. Letters indicate significant differences. 


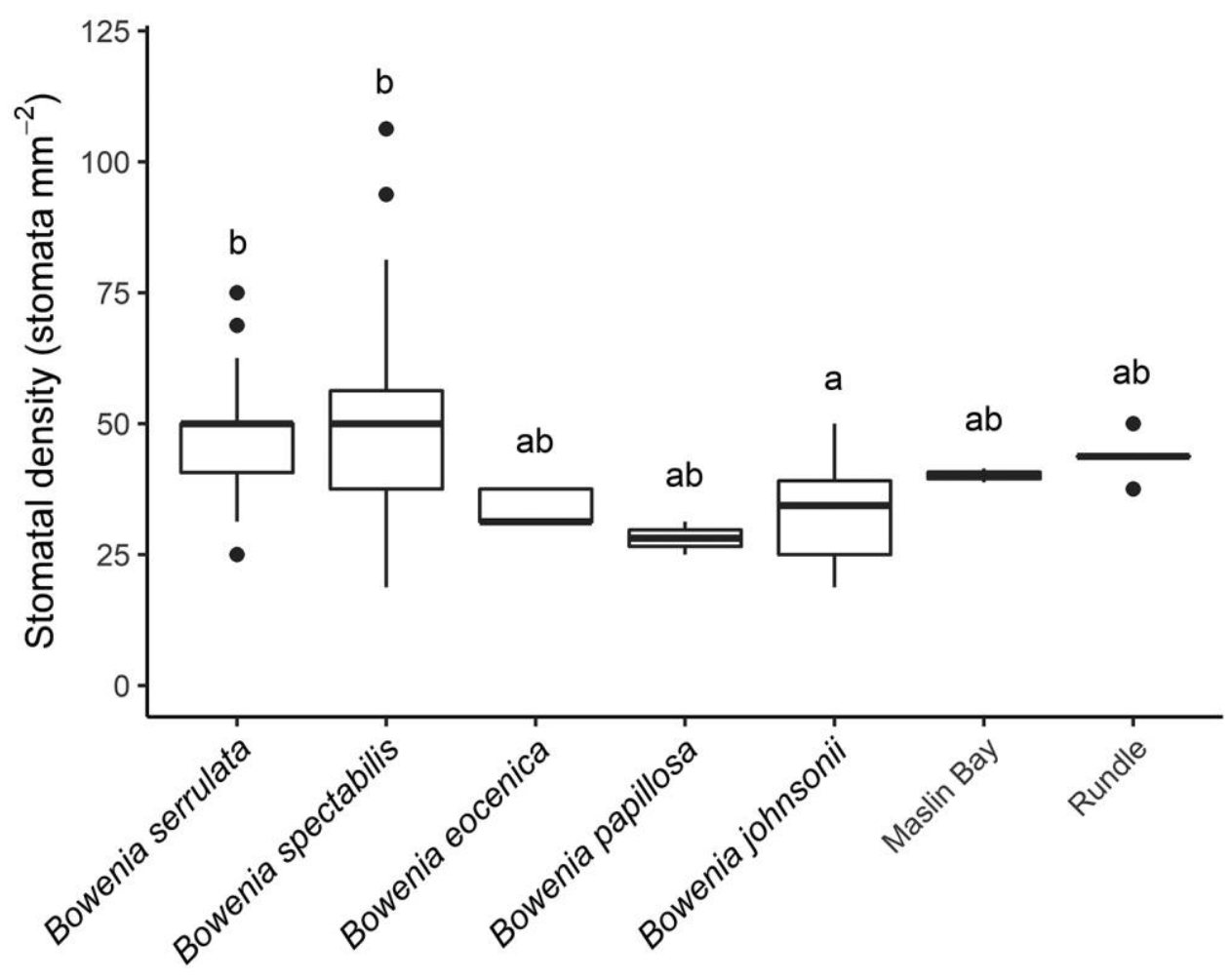

Fig. 5 Boxplots of stomatal density for all measurable known Bowenia species. The top and bottom hinges are the 25th and 75 th percentiles, respectively. The top and bottom whiskers end at the highest or lowest values no larger than a multiple of 1.5 times the interquartile range. Data points extending beyond the whiskers are outliers. Letters indicate significant differences.

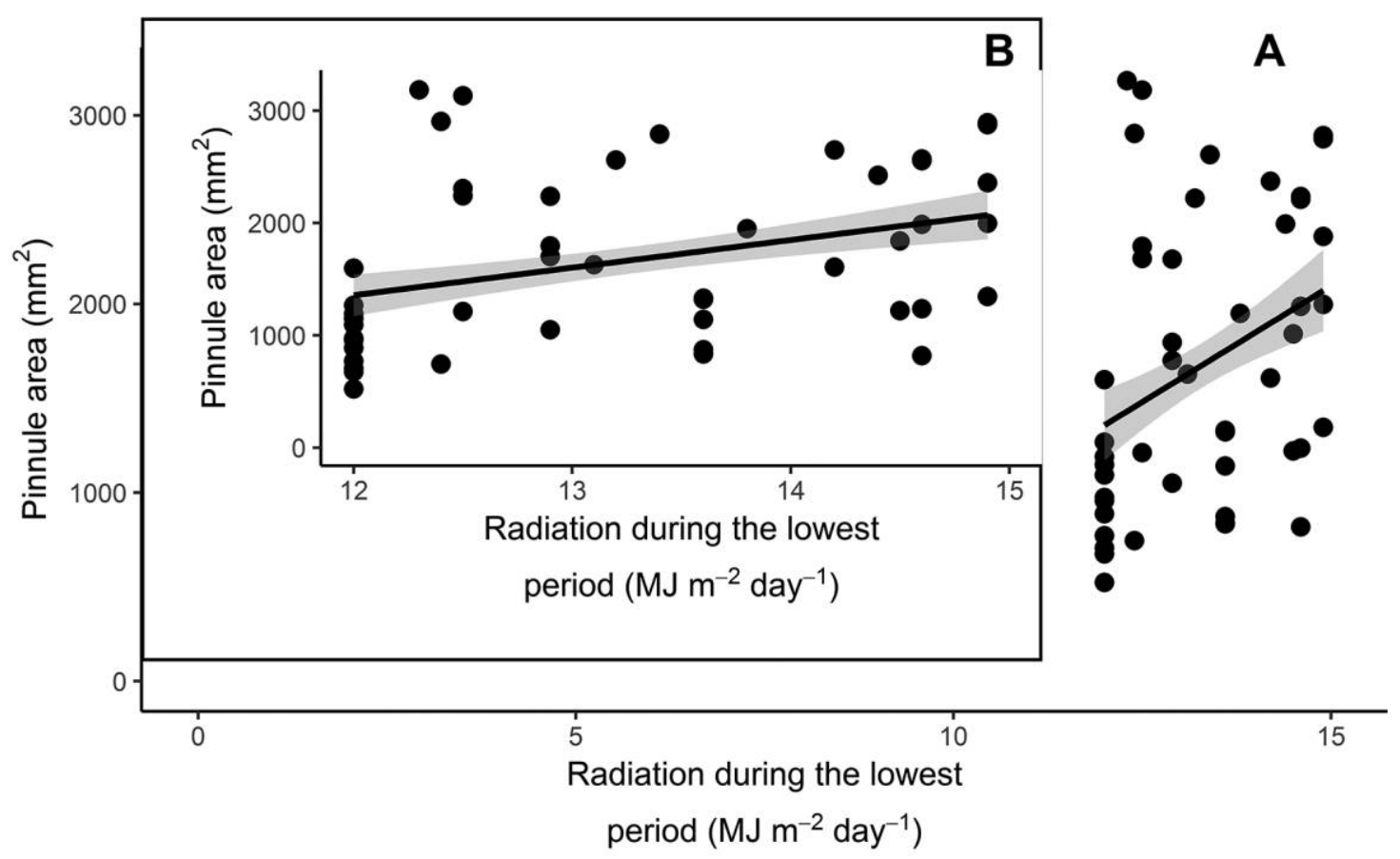

Fig. 6 Relationship between radiation during the lowest period of the day and pinnule area for extant Bowenia species $\left(R^{2}=0.12\right.$, $P<0.0001)$. A, Entire range of radiation. B, Magnified to a $3 \mathrm{MJ} \mathrm{m}^{-2} \mathrm{~d}^{-1}$ span. 


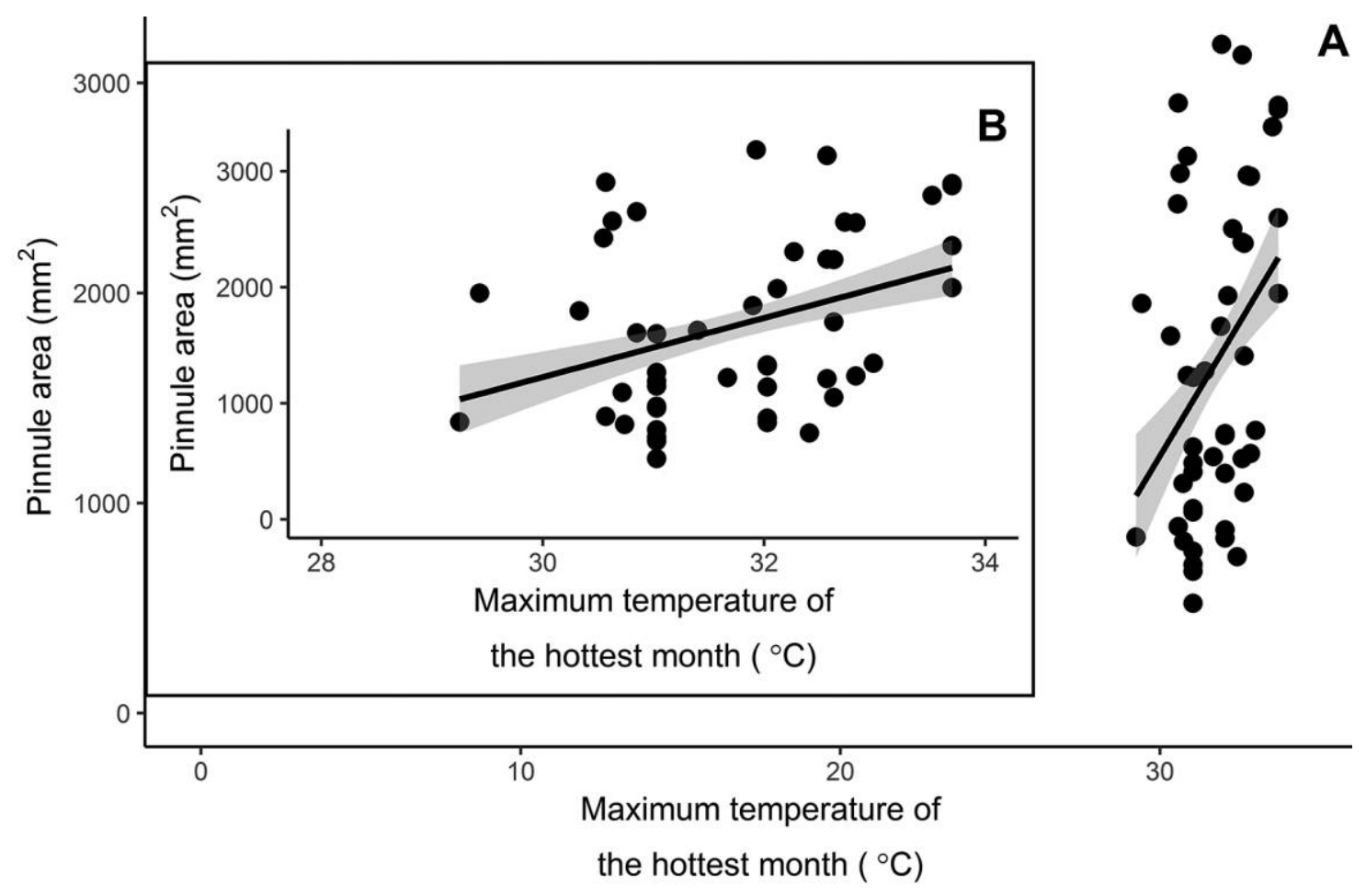

Fig. 7 Relationship between maximum temperature of the hottest month and pinnule area for the extant Bowenia species $\left(R^{2}=0.13\right.$, $P<0.0001)$. A, Entire temperature range. $B$, Magnified to a $6^{\circ} \mathrm{C}$ span.

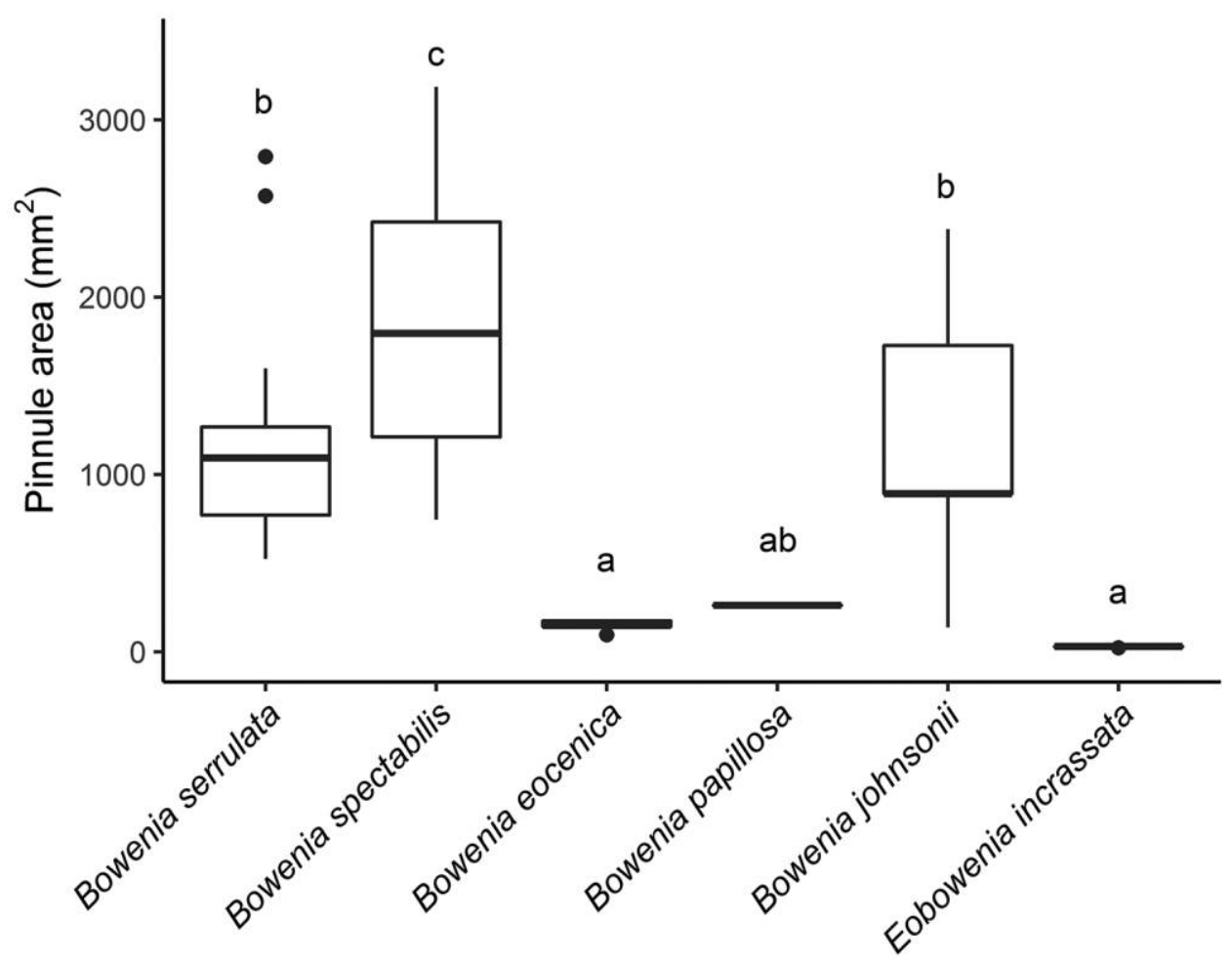

Fig. 8 Boxplots of pinnule area for the two extant and three of the fossil Bowenia species and for Eobowenia. Letters indicate significant differences. 


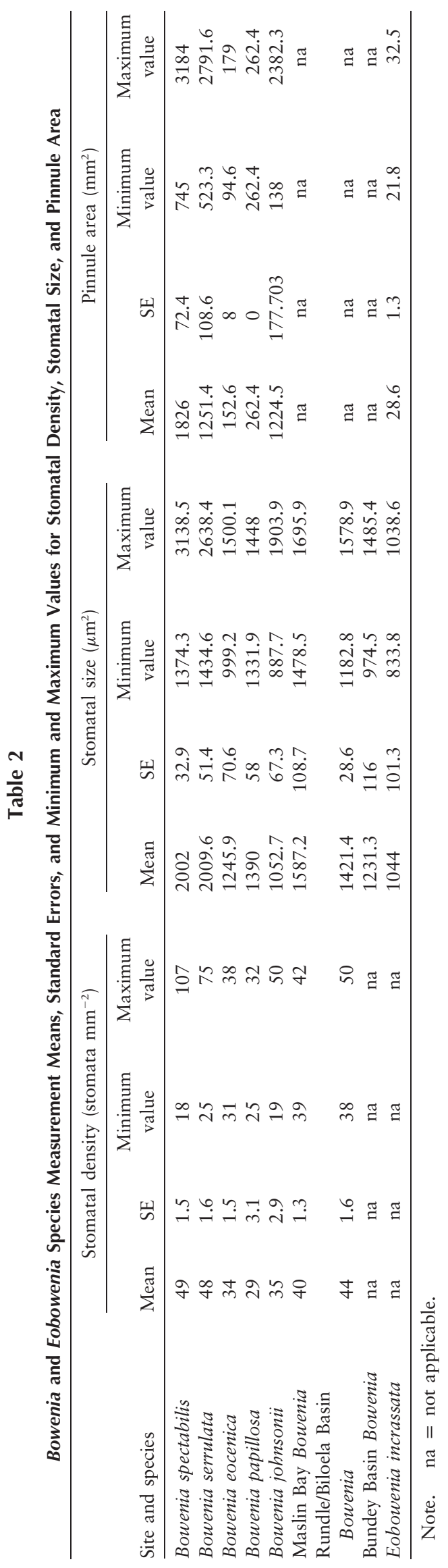

This content downloaded from 129.127.079.196 on August 19, 2019 23:16:29 PM 


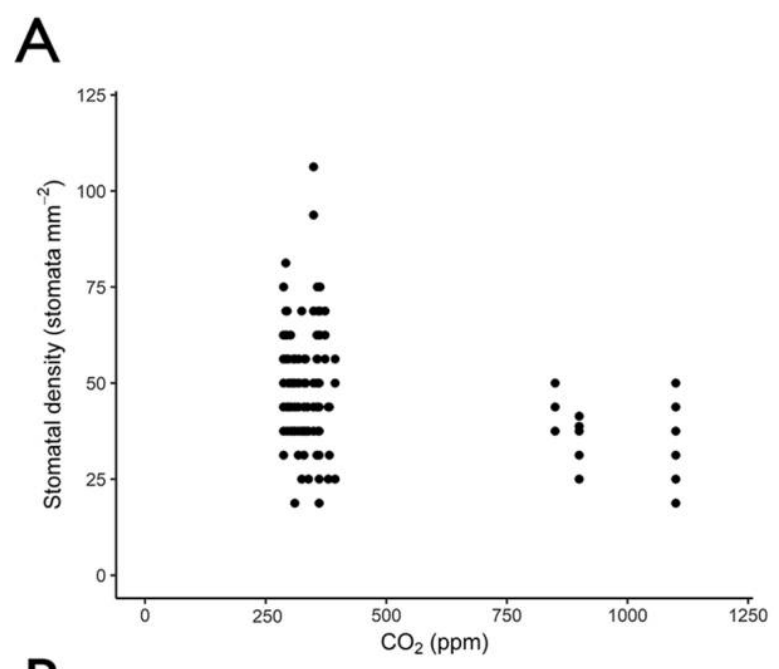

B
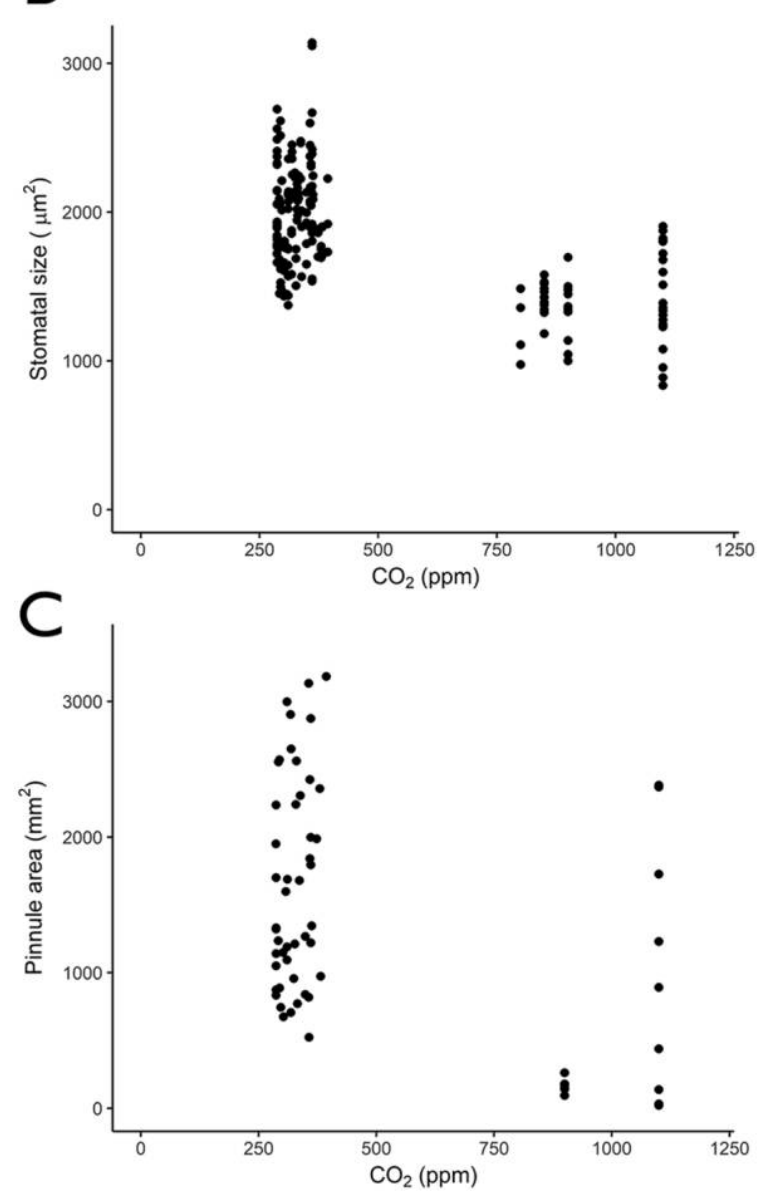

Fig. 9 Single-factor linear correlations between $\mathrm{CO}_{2}$ and stomatal density $\left(A ; R^{2}=0.4, P<0.0001\right)$, stomatal size $\left(B ; R^{2}=0.11\right.$, $P<0.0001)$, and pinnule area $\left(C ; R^{2}=0.17, P<0.0001\right)$. Data points are individual measures.

to ash fall and acid precipitation in an environment with dry periods, although water bodies were present (Limarino et al. 2012). Hence, the recovery of Bowenia and Eobowenia fossils with relatively small pinnules was not expected. While only one fragment of a pinnule has been recovered from Nerriga, there are several complete or near complete pinnules from Anglesea, and they are consistently small (Hill et al. 2018; fig. 2).

By contrast, the pinnules of $B$. johnsonii from Lowana Road in Tasmania are larger and not significantly different from the extant species (fig. 8). The Lowana Road vegetation was distinct from that at Anglesea and Nerriga, with evidence for mangrove vegetation (Pole and Macphail 1996), diverse broadleaved angiosperms (Carpenter et al. 2007; Carpenter et al. 2012), diverse and common conifers (Bigwood and Hill 1985; Hill and Bigwood 1987; Hill 1990), and other gymnosperms (McLoughlin et al. 2008). The vegetation may have been open canopied (Pole 1998). It is possible that the size differences in the fossil Bowenia pinnules reflect the local conditions existing at the different sites.

At Nerriga and Anglesea, Bowenia were probably understory plants and needed to maximize sunfleck capture. While at the Anfiteatro de Ticó Formation, E. incrassata was shaded by ash fall; thus, it also needed to maximize sunfleck capture and minimize self-shading. In contrast, the more complex and probably open vegetation at Lowana Road may have driven the evolution of larger pinnules for the resident Bowenia species.

The high atmospheric $\mathrm{CO}_{2}$ levels during the Eocene means that the Australian fossil plants were not $\mathrm{CO}_{2}$ limited and could have a relatively low density of stomata. The thin boundary layer associated with the small pinnules would have allowed rapid dissipation of water vapor (Nobel 2009). This is potentially advantageous to the plant, as high humidity allowed the germination of fungal spores on the pinnule surfaces (see fig. $1 F, 1 G$ ); thus, any air drying around the pinnule may have reduced fungal growth. The thin boundary layer of the Anfiteatro de Ticó Formation fossil species may have been an advantage during the warm conditions, as it increases convective heat dissipation (Martin et al. 1999).

Carbon dioxide concentrations during the Aptian were up to 2500 ppm (Wang et al. 2014), although they were more likely $1100 \mathrm{ppm}$ and up to $1125 \mathrm{ppm}$ during the Eocene (Lowenstein and Demicco 2006). Stomata were relatively small in the South American E. incrassata growing during the Aptian, and the Australian Bowenia pinnules growing during the Eocene had fewer and smaller stomata than the living species (fig 8). Fewer diffusion sites means that there were fewer diffusion shells around stomata on each pinnule, and these were of a small size due to the small stomatal size (Nobel 2009). Physiologically, there are two likely explanations for this stomatal anatomy; one being that relatively small and few stomata can stay open all the time to allow rapid response to sunflecks, the other being that small stomata can open and close quickly to allow fast response to sunflecks for photosynthesis.

Along with pinnule area, stomatal anatomy may have assisted prevention of fungal growth. Few, small stomata assists avoidance of hyphal invasion through few, small invasion sites. Stomatal ratio, or the ratio of upper to lower stomata on an amphistomatic leaf, is driven by the trade-off between photosynthesis and pathogen resistance (Muir 2015). Although in this article there is not quantified stomatal ratio information, stomata are very rare on the adaxial surface. This trade-off suggests that small stomatal size decreases the likelihood that fungi will encounter a stomatal opening as a potential infection point. There is little information available on the life span of Bowenia 
fronds, but prevention of fungal growth becomes more important the longer the fronds remain functional.

The presence of fewer, smaller stomata in the fossil species is a physical property that creates a short diffusion path length for $\mathrm{CO}_{2}$ to enter and water vapor to escape, and the number of sites available for diffusion is reduced (Nobel 2009). Additionally, in both E. incrassata and fossil Bowenia, the small stomata may have been able to open quickly for sunfleck utility (Drake et al. 2013). Alternatively, rather than affecting $\mathrm{CO}_{2}$ uptake or water loss, as both of these variables were abundant, stomata may have stayed open to allow photosynthesis as soon as a sunfleck hit the pinnule (Elliott-Kingston et al. 2016). The low irradiance at most of the fossil locations could mean that light was more limiting to photosynthesis than was $\mathrm{CO}_{2}$.

We suggest that many climate and environmental factors have contributed to the stomatal and pinnule area changes of these species and that there is not one influencer. Thus, we are not using these data to create a proxy for paleo- $\mathrm{CO}_{2}$ reconstructions. Carbon dioxide would have interacted with many other factors, and thus we deem a reconstruction inappropriate for these species.

This research supports published conclusions that plants at the Anfiteatro de Ticó Formation had limited light availability due to ash fall during the Cretaceous, although the environment was open and water bodies were present. During the Eocene, the plant growth environment of southern Australia consisted of high humidity, low radiation, and high maximum temperatures. The morphology and anatomy of the pinnules allowed Bowenia and Eobowenia to survive in their environments, sometimes through small pinnules reducing self-shading and small and widely spaced stomata reducing the likelihood of fungal infection while still being available to open when light was sporadically available.

\section{Acknowledgments}

We thank the Queensland Herbarium for provision of specimens and laboratory resources, the South Australian Herbarium for the loan of a fossil-type specimen, and the Melbourne Museum for the loan of several specimens. We also thank the Exploration Data Centre of the Geological Survey of Queensland for core samples, Dr. M.K. Macphail for opinions on the palynology of key sites, and two reviewers who improved the manuscript. The research was supported by Australian Research Council grant DP130104314.

\section{Literature Cited}

Anagnostou E, EH John, KM Edgar, GL Foster, A Ridgwell, GN Inglis, RD Pancost, DJ Lunt, PN Pearson 2016 Changing atmospheric $\mathrm{CO}_{2}$ concentration was the primary driver of early Cenozoic climate. Nature 533:380-384.

Archangelsky S 2001 The Ticó flora (Patagonia) and the Aptian extinction event. Acta Palaeobot 41:115-122.

Archangelsky S, A Archangelsky 2013 Aptian angiosperm pollen from the Ticó flora Patagonia, Argentina. Int I Plant Sci 174:559-571.

Basinger JF, DC Christophel 1985 Fossil flowers and leaves of the Ebenaceae from the Eocene of southern Australia. Can I Bot 63: $1825-1843$.

Beerling D, C Kelly 1997 Stomatal density responses of temperate woodland plants over the past seven decades of $\mathrm{CO}_{2}$ increase: a comparison of Salisbury (1927) with contemporary data. Am I Bot 84:1572.

Bettarini I, FP Vaccari, F Miglietta 1998 Elevated $\mathrm{CO}_{2}$ concentrations and stomatal density: observations from 17 plant species growing in a $\mathrm{CO}_{2}$ spring in central Italy. Glob Change Biol 4:17-22.

Bigwood AJ, RS Hill 1985 Tertiary Araucarian macrofossils from Tasmania. Aust I Bot 33:645-656.

Cande SC, JM Stock 2013 Cenozoic reconstructions of the AustraliaNew Zealand-South Pacific sector of Antarctica. Pages 5-17 in The Cenozoic Southern Ocean: tectonics, sedimentation, and climate change between Australia and Antarctica. American Geophysical Union, Washington, DC.

Carpenter RJ, GJ Jordan, RS Hill 2007 A toothed Lauraceae leaf from the early Eocene of Tasmania, Australia. Int I Plant Sci 168:11911198.

2016 Fossil leaves of Banksia, banksieae and pretenders: resolving the fossil genus Banksieaephyllum. Aust Syst Bot 29:126141.

Carpenter RJ, GJ Jordan, MK Macphail, RS Hill 2012 Near-tropical early Eocene terrestrial temperatures at the Australo-Antarctic margin, western Tasmania. Geology 40:267-270.

Carpenter RJ, MK Macphail, GJ Jordan, RS Hill 2015 Fossil evidence for open, Proteaceae-dominated heathlands and fire in the Late Cretaceous of Australia. Am I Bot 102:2092-2107.
Christophel D 1980 Occurrence of Casuarina megafossils in the Tertiary of South-Eastern Australia. Aust I Bot 28:249-259.

1984 Early Tertiary Proteaceae: the first floral evidence for the Musgraveinae. Aust I Bot 32:177-186.

Christophel D, W Harris, A Syber 1987 The Eocene flora of the Anglesea Locality, Victoria. Alcheringa: Australas I Paleaontol 11:303-323.

Christophel DC, SD Lys 1986 Mummified leaves of two new species of Myrtaceae from the Eocene of Victoria, Australia. Aust I Bot 34:649-662.

Coiro M, C Pott 2017 Eobowenia gen. Nov. From the early Cretaceous of Patagonia: indication for an early divergence of Bowenia? BMC Evol Biol 17:97.

Del Fueyo GM 2007 Biodiversidad de las Paleofloras de Patagonia austral durante el Cretácico Inferior. Publicación Electrónica de la Asociación Paleontológica Argentina 11:101-122.

Drake PL, RH Froend, PJ Franks 2013 Smaller, faster stomata: scaling of stomatal size, rate of response, and stomatal conductance. L Exp Bot 64:495-505.

El-Sharkawy M, J Cock, A Hernandez 1985 Stomatal response to air humidity and its relation to stomatal density in a wide range of warm climate species. Photosynth Res 7:137-149.

Elliott-Kingston C, M Haworth, JM Yearsley, SP Batke, T Lawson, JC McElwain 2016 Does size matter? atmospheric $\mathrm{CO}_{2}$ may be a stronger driver of stomatal closing rate than stomatal size in taxa that diversified under low $\mathrm{CO}_{2}$. Front Plant Sci 7:1253.

Etheridge D, L Steele, R Langenfelds, R Francey, J Barnola, V Morgan 1998 Historical $\mathrm{CO}_{2}$ records from the Law Dome DE08, DE08-2, and DSS ice cores. Oak Ridge National Laboratory, US Department of Energy, Oak Ridge, TN.

Falster DS, M Westoby 2003 Leaf size and angle vary widely across species: what consequences for light interception? New Phytol 158 509-525.

Foster C, W Harris 1981 Azolla capricornica sp. nov. First Tertiary record of Azolla Lamarck (Salviniaceae) in Australia. Trans R Soc S Aust 105:195-204.

Francis JE, S Marenssi, R Levy, M Hambrey, VC Thorn, B Mohr, H Brinkhuis, et al 2008 From greenhouse to icehouse: the Oocene/ 
Oligocene in Antarctica. Pages 309-368 in F Florindo, M Siegert, eds. Antarctic climate evolution. Vol 8. Developments in earth and environmental sciences. Elsevier, Oxford.

Frank AB, JF Power, WO Willis 1973 Effect of temperature and plant water stress on photosynthesis, diffusion resistance, and leaf water potential in spring wheat. Agron I 65:777-780.

Franks PJ, D Beerling 2009 Maximum leaf conductance driven by $\mathrm{CO}_{2}$ effects on stomatal size and density over geologic time. Proc Natl Acad Sci USA 106:10343-10347.

Franks PJ, PL Drake, DJ Beerling 2009 Plasticity in maximum stomatal conductance constrained by negative correlation between stomatal size and density: an analysis using Eucalyptus globulus. Plant Cell Environ 32:1737-1748.

Gay AP, RG Hurd 1975 The influence of light on stomatal density in the tomato. New Phytol 75:37-46.

Gindel I 1969 Stomatal number and size as related to soil moisture in tree xerophytes in Israel. Ecology 50:263-267.

Gislerød HR, PV Nelson 1989 The interaction of relative air humidity and carbon dioxide enrichment in the growth of Chrysanthemum $\times$ morifolium ramat". Sci Hortic 38:305-313.

Haworth M, A Fitzgerald, JC McElwain 2011 Cycads show no stomatal-density and index response to elevated carbon dioxide and subambient oxygen. Aust I Bot 59:630-639.

Haworth M, J McElwain 2008 Hot, dry, wet, cold or toxic? revisiting the ecological significance of leaf and cuticular micromorphology. Palaeogeogr Palaeoclimatol Palaeoecol 262:79-90.

Hill KE, GR Guerin, RS Hill, JR Watling 2015 Temperature influences stomatal density and maximum potential water loss through stomata of Dodonaea viscosa subsp. Angustissima along a latitude gradient in southern Australia. Aust I Bot 62:657-665.

Hill RS 1978 Two new species of Bowenia Hook, ex Hook, f. from the Eocene of eastern Australia. Aust I Bot 26:837-846.

1990 Arancaria (Araucariaceae) species from Australian Tertiary sediments: a micromorphological study. Aust Syst Bot 3:203220 .

2004 Origins of the southeastern Australian vegetation. Philos Trans R Soc Lond B Biol Sci 359:1537-1549.

Hill RS, D Christophel 1988 Tertiary leaves of the tribe Banksieae (Proteaceae) from south-eastern Australia. Bot I Linn Soc 97:205227.

Hill RS, K Hill, R Carpenter, G Jordan 2018 New macrofossils of the Australian cycad Bowenia and their significance in reconstructing the past morphological range of the genus. Int I Plant Sci 180: $128-140$.

Hill RS, AJ Bigwood 1987 Tertiary gymnosperms from Tasmania: Araucariaceae. Alcheringa: Aust I Palaeontol 11:325-335.

Krassilov VA 1977 The origin of angiosperms. Bot Rev 43:143-176.

Lange R 1978 Southern Australian Tertiary epiphyllous fungi, modern equivalents in the Australasian region, and habitat indicator value. Can I Bot 56:532-541.

Lake JA, WP Quick, DJ Beerling, FI Woodward 2001 Plant development: signals from mature to new leaves. Nature 411:154.

Laskar J, P Robutel, F Joutel, M Gastineau, A Correia, B Levrard 2004 A long-term numerical solution for the insolation quantities of the earth. Astron Astrophys 428:261-285.

Limarino CO, MG Passalia, M Llorens, EI Vera, VSP Loinaze, SN Césari 2012 Depositional environments and vegetation of Aptian sequences affected by volcanism in Patagonia. Palaeogeogr Palaeoclimatol Palaeoecol 323:22-41.

Limin Y, H Mei, Z Guangsheng, L Jiandong 2007 The changes in water-use efficiency and stoma density of Leymus chinensis along Northeast China Transect. Acta Ecologica Sinica 27:16-23.

Lowenstein TK, RV Demicco 2006 Elevated Eocene atmospheric $\mathrm{CO}_{2}$ and its subsequent decline. Science 313:1928-1928.

Macphail MK, RS Hill, RJ Carpenter, JL McKellar 2014 Cenozoic oil-shale deposits in southeastern-central Queensland: palynostrati- graphic age determinations and correlations for the Biloela Formation (Biloela Basin) in GSQ Monto 5. Queensland Geological Record, Brisbane Geological Survey of Queensland, Australia.

Martin HA 2006 Cenozoic climatic change and the development of the arid vegetation in Australia. I Arid Environ 66:533-563.

Martin TA, TM Hinckley, FC Meinzer, DG Sprugel 1999 Boundary layer conductance, leaf temperature and transpiration of Abies amabilis branches. Tree Physiol 19:435-443.

Matthews JSA, S Vialet-Chabrand, T Lawson 2018 Acclimation to fluctuating light impacts the rapidity of response and diurnal rhythm of stomatal conductance. Plant Phvsiol 176:1939-1951.

McGowran B, W Harris, J Lindsay 1970 The Maslin Bay flora, South Australia. 1. Evidence for an early Middle Eocene age. N Jb Geol Paläont Mh 8:481-485.

McGowran B, RS Hill 2015 Cenozoic climatic shifts in Southern Australia. Trans R Soc S Aust 139:19-37.

McLoughlin S, RJ Carpenter, GJ Jordan, RS Hill 2008 Seed ferns survived the end-Cretaceous mass extinction in Tasmania. Am I Bot 95:465-471.

Miller-Rushing AJ, RB Primack, PH Templer, S Rathbone, S Mukunda 2009 Long-term relationships among atmospheric $\mathrm{CO}_{2}$, stomata, and intrinsic water use efficiency in individual trees. $\underline{\mathrm{Am} \mathrm{I} \mathrm{Bot}}$ 96:1779-1786.

Muir CD 2015 Making pore choices: repeated regime shifts in stomatal ratio. Proc R Soc Lond Biol 282.

Nobel PS 2009 Physicochemical and environmental plant physiology. 4th ed. Academic Press, San Diego, CA.

Passalia M, S Archangelsky, E Romero, G Cladera 2014 A new early angiosperm leaf from the Anfiteatro de Ticó Formation (Aptian), Santa Cruz Province, Argentina. Rev Mus Argentino Cienc Nat, NS, 5:245-252.

Passalia MG, G Del Fueyo, S Archangelsky 2010 An Early Cretaceous zamiaceous cycad of South West Gondwana: Restrepophyllum nov. gen. from Patagonia, Argentina. Rev Palaeobot Palynol 161: 137-150.

Pearcy RW, W Yang 1996 A three-dimensional crown architecture model for assessment of light capture and carbon gain by understory plants. Oecologia 108:1-12.

Pole MS 1998 Early Eocene estuary at Strahan, Tasmania. Aust _ Earth Sci 45:979-985.

Pole MS, MK Macphail 1996 Eocene Nypa from Regatta Point, Tasmania. Rev Palaeobot Palynol 92:55-67.

Prior LD, D Eamus, GA Duff 1997 Seasonal and diurnal patterns of carbon assimilation, stomatal conductance and leaf water potential in Eucalyptus tetrodonta saplings in a wet-dry savanna in Northern Australia. Aust I Bot 45:241-258.

Rasband WS 1997-2014 ImageJ. US National Institutes of Health, Bethesda, MD.

Rowett AI 1988 The megafossil and microfossil floras of the Curlew Formation, Queensland. PhD thesis. University of Adelaide, Australia.

RStudio Team 2015 RStudio: integrated development for r. RStudio, Boston.

Shellito CJ, LC Sloan, M Huber 2003 Climate model sensitivity to atmospheric $\mathrm{CO}_{2}$ levels in the Early-Middle Paleogene. Palaeogeogr Palaeoclimatol Palaeoecol 193:113-123.

Sloan LC, DK Rea 1996 Atmospheric carbon dioxide and early eocene climate: a general circulation modeling sensitivity study. Palaeogeogr Palaeoclimatol Palaeoecol 119:275-292.

Tans P, R Keeling 2017 Mauna Loa $\mathrm{CO}_{2}$ monthly mean data. www .esrl.noaa.gov/gmd/ccgg/trends/scrippsco2.ucsd.edu/5/4/2017

Truswell E, J Owen 1988 Eocene pollen from Bungonia, New South Wales. Mem Assoc Australas Palaeontol 5:259-284.

Villar de Seoane L 2005 New cycadalean leaves from the Anfiteatro de Ticó Formation, Early Aptian, Patagonia, Argentina. Cretac Res 26:540-550. 
Wang Y, C Huang, B Sun, C Quan, J Wu, Z Lin 2014 Paleo-CO variation trends and the cretaceous greenhouse climate. Earth-Sci Rev 129:136-147.

Wellman P, I McDougall 1974 Potassium-argon ages on the Cainozoic volcanic rocks of New South Wales. I Geol Soc Aust 21:247-272.

Wilford G, P Brown 1994 Maps of late Mesozoic-Cenozoic Gondwana break-up: some palaeogeographical implications. Pages 5-13 in R Hill, ed. History of the Australian vegetation: Cretaceous to recent. Cambridge University Press, Cambridge.

Woodward FI 1987 Stomatal numbers are sensitive to increases in $\mathrm{CO}_{2}$ from pre-industrial levels. Nature 327:617-618.

Wright IJ, N Dong, V Maire, IC Prentice, M Westoby, S Díaz, RV Gallagher, BF Jacobs, R Kooyman, EA Law 2017 Global climatic drivers of leaf size. Science 357:917-921. 